\title{
New data on pre-Eocene karst in the Tatra Mountains, Central Carpathians, Poland
}

\author{
Renata JACH ${ }^{1}$, Michał GRADZIŃSKI ${ }^{1, *}$ and Helena HERCMAN ${ }^{2}$ \\ 1 Jagiellonian University, Institute of Geological Sciences, Oleandry 2a, 30-063 Kraków, Poland \\ 2 Polish Academy of Sciences, Institute of Geological Sciences, Twarda 51/55, 00-818 Warszawa, Poland
}

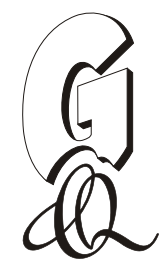

Jach, R., Gradziński, M., Hercman, H., 2016. New data on pre-Eocene karst in the Tatra Mountains, Central Carpathians, Poland. Geological Quarterly, 60 (2): 291-300, doi: 10.7306/gq.1281

\begin{abstract}
Sparry limestone, ferruginous muddy limestone and limestone breccia have been found in the Western Tatra Mts. They occur within Jurassic rocks of the Choč Nappe just below red conglomerates of probable Eocene age. The deposits found bear strong resemblance to the infill of subterranean karst forms. They differ significantly from Quaternary karst deposits of the Tatra Mts. The $\delta^{18} \mathrm{O}$ values of spelean carbonates suggest crystallisation at relatively high temperatures (over $20^{\circ} \mathrm{C}$ ) whereas their relatively negative $\delta^{13} \mathrm{C}$ values imply the presence of soil-derived $\mathrm{CO}_{2}$ linked with vegetation dominated by $\mathrm{C} 3$ pathway plants. The karst forms and their infill were formed before the Eocene transgression, which shows unequivocally that the Tatra Mts. were subjected to karstification at that time.
\end{abstract}

Key words: cave deposits, speleothems, weathering, Paleogene.

\section{INTRODUCTION}

Several periods of non-deposition in subaerial conditions occurred in the geological history of the Tatra Mts. Bearing in mind that the area is composed predominantly of carbonate rocks, one can expect not only weathering, but also the development of karst phenomena during these periods. At least four phases of karstification have been recognized in the Tatra Mts. - namely: Triassic (Anisian, and Ladinian/Carnian), Early Cretaceous (Aptian/Albian), mid-Cretaceous to Eocene, and post-Eocene (Głazek, 1989; Gradziński et al., 2009 and references therein). The karstification between the mid-Cretaceous and Eocene is named pre-Eocene hereafter in this paper.

This pre-Eocene karstification was primarily postulated by Kuźniar (1913), who also compared red-stained rock occurring at the base of the Eocene transgressive sequence to continental "siderolitique formations" known from Switzerland. Wyczółkowski (1956) associated Eocene red conglomerate to be continental in origin. Later, this view was questioned by Roniewicz (1969), who regarded red conglomerate as a transgressive marine deposit and considered its colouration as resulting from of the occurrence of red-stained limestone in the basement. Concomitantly, Roniewicz (1969) noted that Eocene red conglomerate in the area of Hruby Regiel was laid dawn on an uneven, karstified surface of the oldest rocks present and

\footnotetext{
* Corresponding author, e-mail: michal.gradzinski@uj.edu.pl
}

Received: October 23, 2015; accepted: January 7, 2016; first published online: February 29, 2016 that the conglomerates in question are locally underlain by breccias with a red-stained matrix. He noticed that the contact between breccia and overlying red conglomerate is gradual. The suggestion of the presence of a karstified surface below Eocene red conglomerates was also made by Passendorfer (1978: p. 207). Uchman $(1997,2014)$ described the occurrence of breccia with a red-stained matrix within Jurassic rocks of the Choč Nappe which directly underlie the red conglomerates. Głazek $(1989,2000,2004)$ summarized previous opinion about the geological history of the Tatra Mts. between nappe thrusting and the Eocene transgression and ascribed a karst origin to the breccias in question. Moreover, he postulated the presence of an extensive polje in the area of the present Hruby Regiel before the Eocene transgression. Gradziński et al. (2006) provided indirect proof of pre-Eocene karstification. They suggested that Mesozoic rocks in the Tatra Mts. must have been karstified before the Eocene transgression, based on the occurrence of calcareous tufa, encompassing calcite-encrusted freshwater algae, within Eocene conglomerate in the Sucha Woda Valley. Findings of speleothem clasts in Eocene conglomerates near the village of Húty (western part of the Tatra Mts.) mentioned by Gross et al. (1993: p. 70) also implies the existence of pre-Eocene karst there. Although many suggestions as summarized above have been put forward, no unequivocal proof on pre-Eocene karstification of the Tatra Mts. has been provided so far.

Conversely, there exist several papers describing or mentioning pre-Eocene karst forms and karst deposits from other mountain massifs of the Central Carpathians. Some analogues to that in the Tatra Mts. includes a karst form filled with bauxite at Mojtín (Strážovské vrchy, Slovakia; Číčel, 1958; Andrusov, 1965: pp. 228, 229, 232). The bauxite is hypothesized to be Senonian in age (Aubrecht, 2015). Other karst localities of simi- 
lar age also filled with bauxite were recognized in the Little Carpathians (Male Karpaty; Činčura, 1998b). Some karst forms originated and filled with internal deposits before the Eocene transgression have been noted from various massifs of the Central Carpathians (Bosák et al., 1989; Činčura and Köhler, 1995; Činčura, 1998a; Novotný and Tulis, 2002; Osborne, 2007). Such forms must also have been destroyed during the Eocene transgression since rare spelothem clasts have been found within Eocene marine conglomerates (Gross et al., 1993: p. 70; Starek et al., 2012). The occurrence of 13 layers of enigmatic Lower Eocene freshwater limestones known as the "Malenica limestone" or "Malenica onyxite" and interpreted as deposited in a fluvial regime (Salaj, 1991, 1993, 2001, 2002) also suggest karstification of older carbonate rocks at that time. The precise age of karstification is difficult to assess. It postdates the thrusting of the Central Carpathian nappes and predates the Eocene transgression. In some areas it predates the deposition of the so-called Gosau beds of Late Cretaceous age, whereas in others it is ascribed to the Paleogene (Bosák et al., 1989).

This paper focuses on pre-Eocene karst in the Tatra Mountains. The main aim is to provide unambiguous evidence that the area in question was karstified before the Eocene transgression. The paper is based on the specimens found in the course of a field study carried out in the area where Eocene red conglomerate directly overlies Mesozoic carbonate of the Choč Nappe. The area is normally devoid of natural exposures, being mantled with a relatively thick soil cover and densely vegetated. The field study was possible due to an extremely strong wind that in December 2013 devastated the forest and cleared the area. The windfall formed many pits, where rock debris appears from below the soil cover (Fig. 1A). It created a unique opportunity to seek traces of pre-Eocene karst deposits.

\section{GEOLOGICAL SETTING}

Middle-Upper Eocene deposits crop out along the northern margin of the Tatra Mts. (Fig. 2; Roniewicz, 1969). These deposits discordantly covered various Mesozoic sedimentary rocks that composed several nappes of the Tatra Mts. The nappes were thrusted northward during the mid-Cretaceous. The Eocene sequence records progressive deepening of the depositional setting (Roniewicz, 1969; Kulka, 1985; Olszewska and Wieczorek, 1998; Bartholdy et al., 1999). The sequence commences with conglomerates composed of Mesozoic bedrock clasts (Fig. 2), overlain by littoral extraclastic packstones which grade up the section into various types of limestone commonly including large benthic foraminifers (Roniewicz, 1969; Machaniec et al., 2011; Jach et al., 2012; Jach and Machaniec, 2014). Conglomerates and marls occur subordinately (Alexandrowicz and Geroch, 1963; Olszewska and Wieczorek, 1998). The whole sequence represents the Bartonian-Priabonian. However, the basal conglomerates are devoid of fossils, and so their age is only hypothesized as Early Bartonian based on their position in the sequence. The Eocene carbonates are succeeded by a succession about $2.5 \mathrm{~km}$ thick of Oligocene turbiditic deposits (Radomski, 1958; Sotak et al., 2001). In the Miocene the Tatra Mts. were uplifted along a prominent boundary fault to the north.

The Mesozoic rocks in the area studied are mainly composed of Lower Jurassic carbonate and siliceous rocks of the Choč Nappe (Bac-Moszaszwili et al., 1979). They represent several facies (Uchman, 1994, 1997, 2014) including peloidal calcarenites (Upper Sinemurian), crinoidal-bioclastic calcarenites (Upper Sinemurian-Upper Pliensbachian), crinoidal calcarenites (Pliensbachian) and spiculites (Pliensbachian). Some carbonates, and more commonly the spiculites, are silicified. These rocks represent the Miętusia Formation (Lefeld et al., 1985) and form two thrust-sheets: the Brama Kantaka thrust-sheet and the Kończysta Turnia thrust-sheet (Kotański, 1965; Grabowski, 1967). They overlie Lower Cretaceous marls of the Krížna Nappe.

The Mesozoic rocks are directly overlain by red conglomerate. Its thickness is estimated to $50 \mathrm{~m}$. It occurs exclusively at the foot of the Western Tatra Mts., namely between the Mała Łaka Valley (to the east) and the Lejowa Valley (to the west). This deposit is poorly exposed and, hence, it is somewhat enigmatic in terms of its characteristics and origin. The exploratory observations carried out in the course of this study show the presence of cross-bedded sandstones and distinctively graded beds within the red conglomerate (Fig. 1B).

\section{MATERIALS AND METHODS}

The detailed field study along the contact zone between the red conglomerates and the basement Mesozoic carbonates
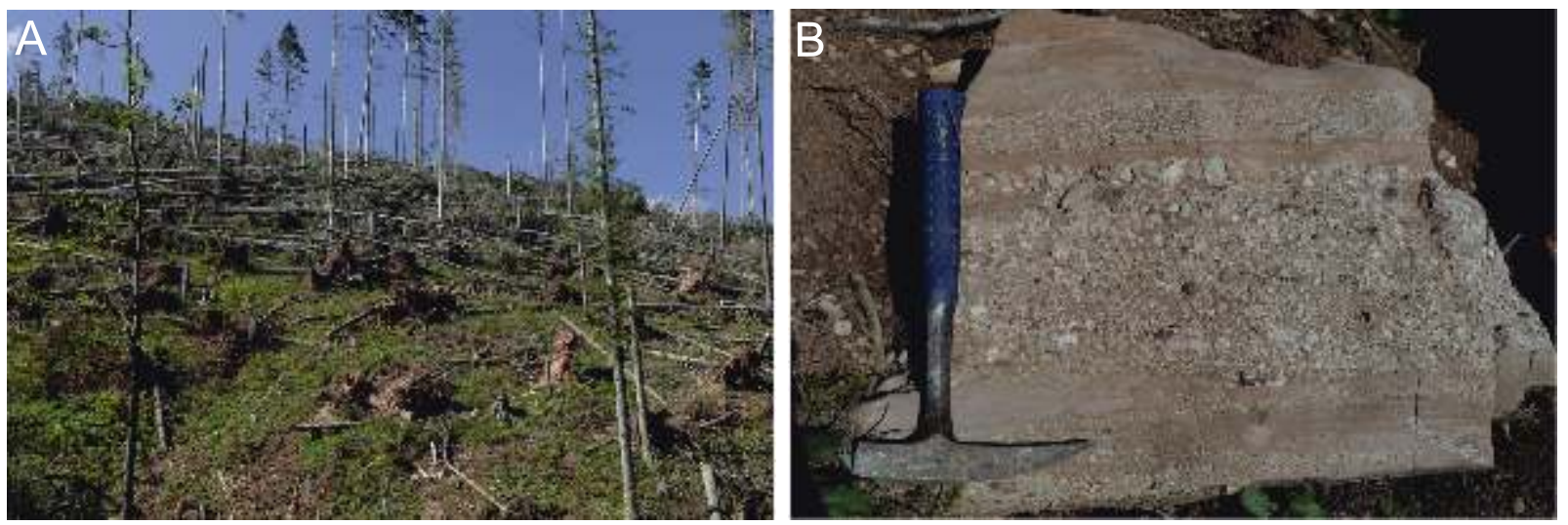

Fig. 1A - western slope of the Kościeliska Valley after a strong wind in December 2013; windfall with numerous windfall tree pits is visible; B - sandstone layers and graded conglomerates within red conglomerate succession 


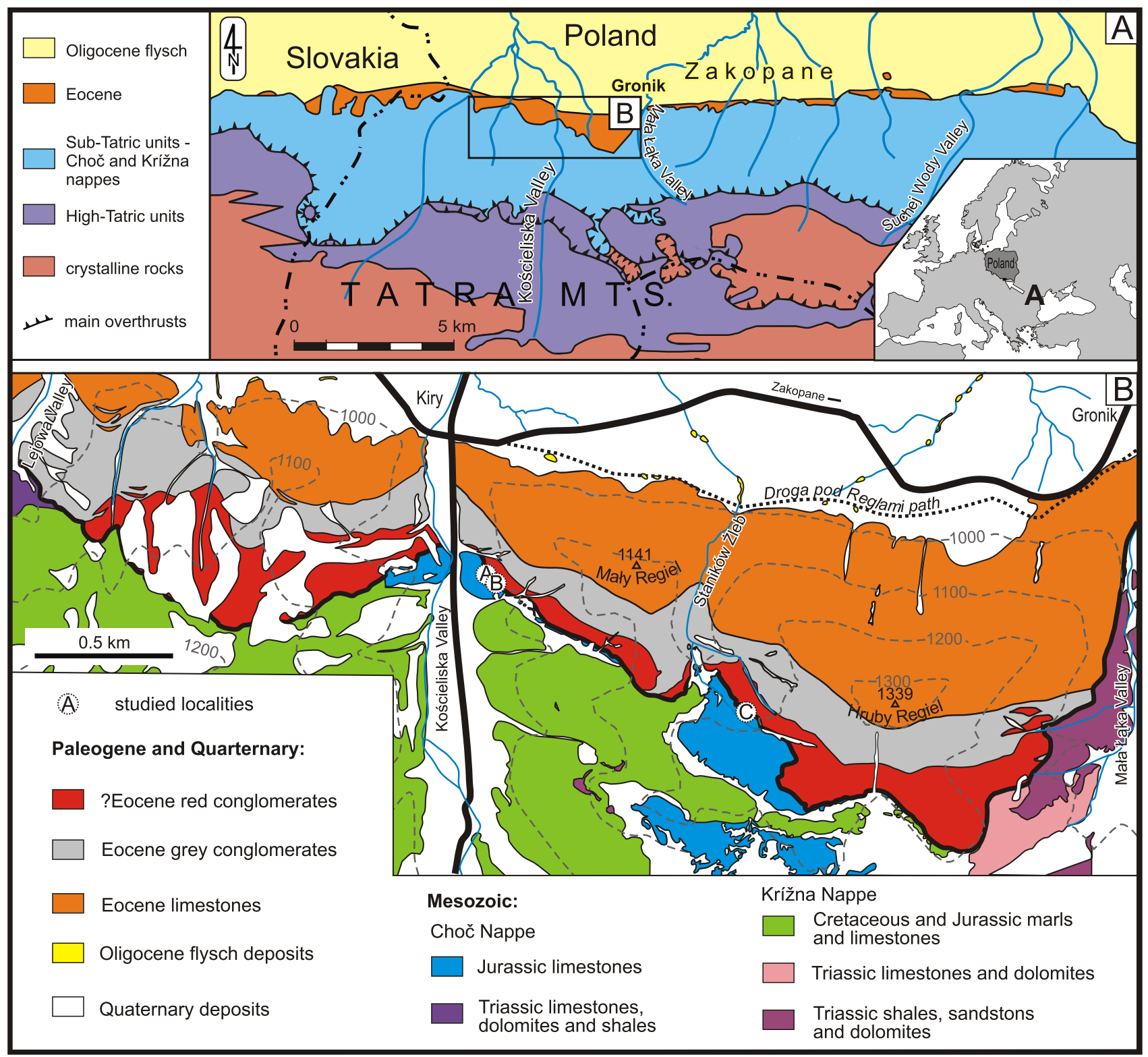

Fig. 2. Location of the sites studied; geological map in A after Bac-Moszaszwili et al. (1979), in B after Sokołowski (1959); modified

was undertaken with special consideration paid to windfall tree pits. Samples of breccia, red-stained carbonate rock and cement visible with the naked eye were collected. The internal structures of the samples were observed in polished sections. The GSA Color Chart (Goddard et al., 1970) was used to determine lithotype colour. The study was extended by observation of thin sections under a standard petrographic optical microscope and under a field emission SEM Hitachi S-4700, equipped with a NORAN Vantage energy dispersive spectrometer (EDS).

For measurements of stable carbon and oxygen isotope ratios of the carbonates, samples were taken with a Dremel drilling machine. The stable isotope composition was analysed at the Warsaw Isotope Laboratory for Dating and Environment Studies of the Polish Academy of Sciences. The samples were dissolved in $100 \%$ phosphoric acid at $70^{\circ} \mathrm{C}$, using a Kiel IV online carbonate preparation device, connected to a Thermo-
-Finnigan Delta Plus mass spectrometer. The quality of the analysis was controlled by NBS-19 international standard measurements. The $\delta^{13} \mathrm{C}$ and $\delta^{18} \mathrm{O}$ values are given relative to the $\mathrm{V}-\mathrm{PDB}$ standard. Analytical reproducibility was verified on the basis of the repeatability of the NBS-19 results, with an observed deviation of $<0.07 \%$ ofor $\delta^{13} \mathrm{C}$ and $<0.12 \%$, for $\delta^{18} \mathrm{O}$ measurements.

Chemical separation of $U$ and $T h$ from the carbonate matrix was carried out in the Institute of Geological Science, Polish Academy of Sciences, Warsaw, Poland. Uranium and thorium were separated from the carbonate matrix using TRU-Spec resin. Prior to any chemical treatment, a mixture of ${ }^{229} \mathrm{Th}^{233} \mathrm{U}-{ }^{236} \mathrm{U}$ was added as a spike. Organic matter was removed from sample by ignition in an oven. The spiked sample was dissolved in concentrated nitric acid. Any insoluble residue was removed by centrifuging. A sample was loaded into the columns with the TRU-resin in $1 \mathrm{M}$ nitric acid. Carbonate matrix 
was removed with acid then $U$ and Th were washed from the columns with mixtures of $0.1 \mathrm{M} \mathrm{HNO}_{3}+0.2 \mathrm{M} \mathrm{HF}$. After evaporation, the sample was dissolved in $10 \%$ nitric acid. Measurements were performed with a double-focusing sector-field ICP mass analyzer (Element 2, Thermo-Finngan MAT in Institute of Geology, Czech Academy of Science, Prague, Czech Republic). The instrument was operated at a low mass resolution $(\mathrm{m} / \Delta \mathrm{m} \geq 300)$. A double pass spray chamber with teflon nebulizer was used as the sample-introduction system.

\section{RESULTS}

\section{PETROGRAPHY OF DEPOSITS}

Three lithotypes have been distinguished: (i) sparry limestone, (ii) ferruginous muddy limestone, and (iii) limestone breccia. They have been found in three localities, two at Kantaka Gate and one in Staników Gully. Table 1 shows the precise location of each locality and the lithotypes found there (see also Figs. 1 and 2). All of them occur in recent scree exposed in fallen tree pits. The direct contact with basement rock is invisible or only visible in part. All the localities are on limestones of the Choč Nappe but very close to the lower boundary of the overlying Eocene deposits. The distance from the contact can be estimated as $<10 \mathrm{~m}$ at each locality.

Sparry limestone. The thickness of sparry limestone varies between a few millimetres and $12 \mathrm{~cm}$ (Fig. 3A-C). The samples show layering visible with the naked eye. The dominant layers are dark yellowish brown (10 YR 4/2). They alternate with layers that are greyish orange in colour (10 YR 7/4). The boundaries between layers are clearly visible. The layers are up to $4 \mathrm{~mm}$ in thickness. Generally, their shape is slightly curved; only in some zones do they form distinct syn- and antiforms. Growth cavities may have formed between neighbouring antiforms.

Sparry limestones are composed mainly of elongated crystals of columnar shape the length: width ratio of which does not exceed 6:1 (Fig. 4A). The crystal length is $>2 \mathrm{~mm}$ whereas their maximal width exceeds $0.5 \mathrm{~mm}$. These crystals form columnar proper fabrics (sensu Frisia and Borsato, 2010) or columnar compact fabrics (sensu Frisia, 2015). More elongated crystals with length:width ratios exceeding 6:1 occur subordinately (Fig. 4B). They correspond to elongated columnar fabric (sensu Frisia and Borsato, 2010; Frisia, 2015). Microcrystalline calcite is very rare. It builds distinctive laminae up to $0.4 \mathrm{~mm}$ in thickness, enriched in non-carbonate grains (e.g., quartz, Fig. 4C).

The columnar crystals are densely packed; there is a lack of intercrystalline porosity. Columnar calcite crystals developed according to competitive growth (Fig. 4A; sensu González et al., 1992) or an impingement crystallisation pattern (sensu Dickson, 1993). The width of crystals increases upwards from

Table 1

Location of the deposits studied

\begin{tabular}{|l|c|c|}
\hline \multicolumn{1}{|c|}{ Location } & Coordinates & Lithotypes \\
\hline Kościeliska Valley, & $49^{\circ} 16^{\prime} 17^{\prime \prime} \mathrm{N}$ & sparry limestone \\
Kantaka Gate & $19^{\circ} 52^{\prime} 11^{\prime \prime} \mathrm{E}$ & ferruginous muddy limestone \\
\hline Kościeliska Valley, & $49^{\circ} 16^{\prime} 17^{\prime \prime} \mathrm{N}$ & sparry limestone \\
Kantaka Gate & $19^{\circ} 52^{\prime} 12^{\prime \prime} \mathrm{E}$ & breccia \\
\hline Staników Gully & $49^{\circ} 16^{\prime} 18^{\prime \prime} \mathrm{N}$ & sparry limestone \\
& $19^{\circ} 52^{\prime} 18^{\prime \prime} \mathrm{E}$ & breccia \\
\hline
\end{tabular}

the nucleation surface, whereas their optic orientation becomes more uniform. The crystals overgrowing monocrystalline fragments of crinoidal limestone display specific optic arrangements. They derive optic orientation from their basement, hence they grew syntaxially.

Ferruginous muddy limestone. Ferruginous muddy limestone is pale red (5R 6/2), moderate reddish orange (10 R 6/6) to dark reddish brown (10 $\mathrm{R} 3 / 4)$. It forms veinlets penetrating down the Jurassic basement rocks, occurs as matrix in breccia which is composed of Jurassic rock fragments or fills growth cavities within sparry limestone (Fig. 3D). Such breccias were noted at locality A. Similar breccias were earlier mentioned from rock crags located in the Staników Gully (Uchman, 1997) and at the Kantaka Gate in the Kościeliska Valley (Głazek, 2000). The limestone host rock along a contact with a veinlet is rounded, which suggests dissolution prior to filling of a veinlet.

The ferruginous muddy limestone is generally poorly cemented. It is exceptionally well-cemented only when it co-occurs with sparry limestone or breccia (Figs. $3 A$ and 4C, D).

Ferruginous muddy limestone is composed of extraclasts derived from older carbonate rocks. Thus, they represent calclithite rock. Single crystals, being disintegrated parts of crinoidal limestone, are most common. The extraclasts are densely packed, with common grain-to-grain contacts; they form a grain-supported texture. The cement completely fills spaces between the extraclasts. The cement has a dark reddish, homogeneous appearance in transmitted light; in some places it is almost opaque (Fig. 4D). Observation under SEM and EDS analyses reveals the presence of fine aluminosilicate particles and microcrystalline carbonate - most probably calcite cement. Some zones are enriched with iron oxide or iron hydroxide cement (up to 46 wt.\% of $\mathrm{Fe}_{2} \mathrm{O}_{3}$ ).

Breccia. Breccia has been found at all three sites. It comprises clasts with a size range mainly of $1-6 \mathrm{~cm}$ (Fig. 3B, E, F). Clasts are angular to subangular in shape, moderate brown to grey in colour with white coarsely crystalline veinlets. They consist of a variety of carbonate and siliceous rock types. Crinoidal, crinoidal-bioclastic, bioclastic packstone and grainstone clasts are most common. Clasts of microsparite limestone and spiculite occur as well. Some of these, mainly the spiculites, are silicified. All these clasts were derived from basement rocks of the Choč Nappe (see Uchman, 2014).

The breccia contains red matrix with a composition similar to that of the ferruginous muddy limestone. Some zones of breccia are cemented with sparry cement analogous to the sparry limestone described above.

\section{ISOTOPIC COMPOSITION}

Each lithotype distinguished has its own characteristic composition of stable carbon and oxygen isotopes (Fig. 5 and Table 2). The differences are more easily visible as regards the stable carbon isotopes. Sparry limestone and sparry cement of limestone breccia have the most negative values of $\delta^{13} \mathrm{C}$ ranging from -10.1 to $-6.31 \%$. Ferruginous muddy limestone displays more positive values of $\delta^{13} \mathrm{C}$ - between -3.40 and $-0.64 \%$. The stable carbon isotope composition of the Mesozoic rock clasts falls within a broad range typical of marine limestones. Partly silicified rock serves as the exception; values of its $\delta^{13} \mathrm{C}$ are more negative.

Results of uranium isotope dating are given in Table 3. Age estimation is impossible since the ${ }^{230} \mathrm{Th} /{ }^{234} \mathrm{U}$ activity ratio is over 1 (see Ivanovich and Harmon, 1992). This suggests open system behaviour. Such a ratio does not result from Th excess since Th is generally stable and remains bounded. Rather, it is 

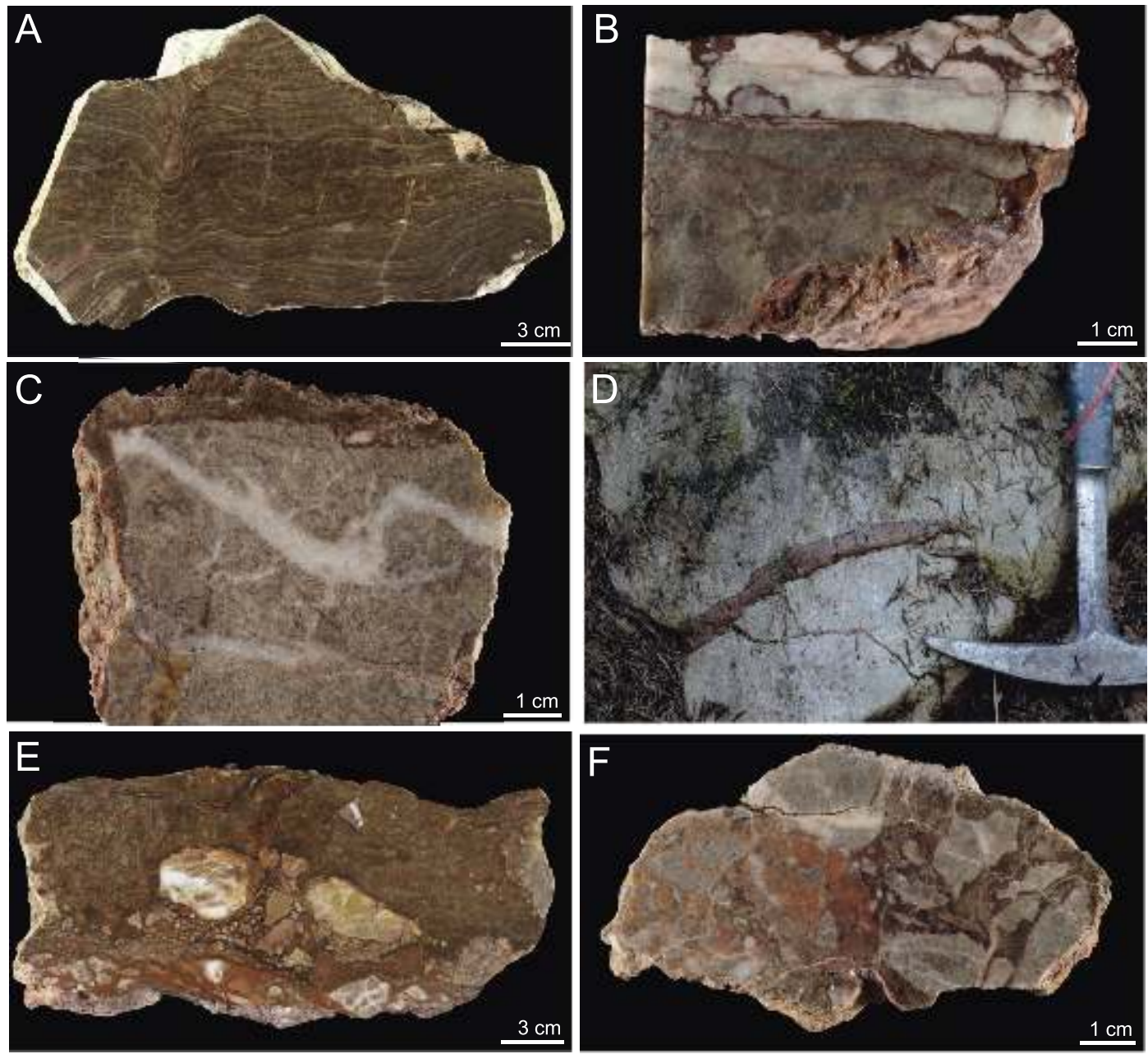

Fig. 3. Macroscopic view of lithotypes found

A-C - sparry limestone, note growth cavity filled with ferruginous muddy limestone in B, sparry limestone in B is developed on a breccia composed of crushed coarse crystalline veinlets, ferruginous muddy limestone acts as a matrix; D - ferruginous muddy limestone which forms a veinlet within Jurassic bedrock limestone; E, F - breccia composed of clasts of Jurassic rocks and ferruginous muddy limestone cemented with sparry limestone

caused by $U$ migration. The content of ${ }^{232} \mathrm{Th}$, which is an indicator of detrital Th, is at the level of $68 \mathrm{ppb}$ and the ${ }^{230} \mathrm{Th} /{ }^{232} \mathrm{Th}$ activity ratio is $>20$ which is accepted as a "threshold value" (see Schwarcz and Latham, 1989).

\section{DISCUSSION}

\section{ORIGIN OF DEPOSITS FOUND}

All the deposits found bear the strong resemblance to infills of karst forms. What they have in common is:

- textures,

- stable isotopic composition (both carbon and oxygen).

Sparry limestone and sparry cements in the breccia show all the characteristic features of spelean calcite. Lamination with syn- and antiforms reflects the morphology of a flowstone with vertical ribs. The empty spaces between neighbouring ribs were partly filled with ferruginous muddy limestone (Fig. 3A). The flowstones discussed are composed predominantly of sparite calcite crystals. The spatial organization of the crystals suggests that sparry limestone grew on a cave wall as a flowstone cover whereas the microscopic features imply that it was fed with a water film flowing down the cave wall. Columnar fabric is typical of a speleothem growing from moderately to highly supersaturated solutions (cf. González et al., 1992; Gradziński et al., 1997; Frisia and Borsato, 2010; Frisia, 2015). Some elongated crystals probably grew during episodes of higher supersaturation (cf. Given and Wilkinson, 1985). The presence of the nucleation surfaces marked with impingement growth of a new generation of crystals shows, on the one hand, interruptions in the crystallisation of the speleothems studied and, on the other hand, the lack of strong diagenetic recrystallisation. The scarcity of detrital components, as shown by microscopic observations and supported additionally by the ${ }^{230} \mathrm{Th} /{ }^{232} \mathrm{Th}$ ratio, suggests that the water supplying the ions was relatively clean.

Thus, all the data collectively indicate that the sparry limestone represents fragments of flowstones which grew within caves. Later, during destruction of the caves, the flowstones were exposed at the surface and fragmented. Similarly, the 

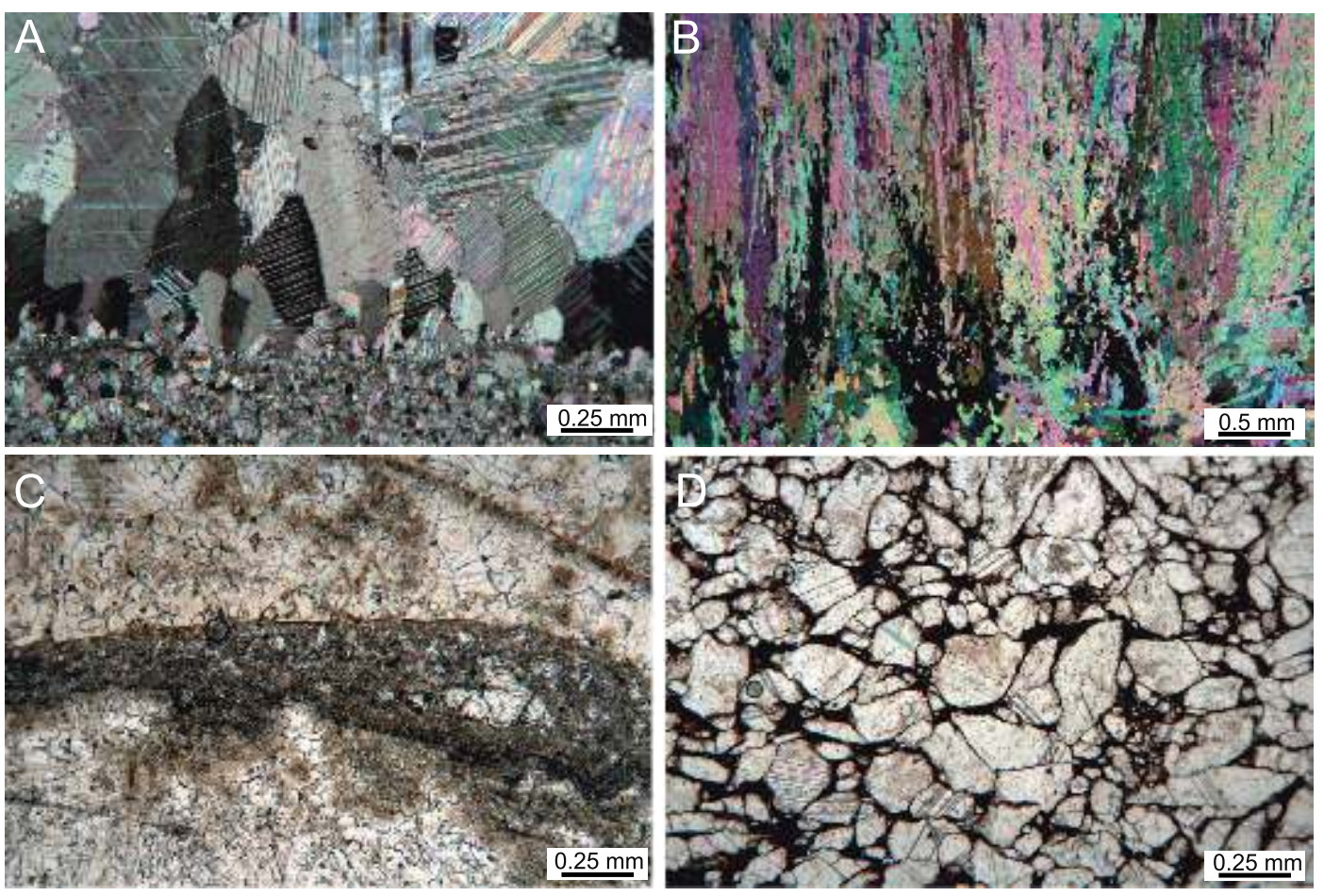

Fig. 4. Microscopic features of the lithotypes found

A - columnar calcite growing on Jurassic limestone, note impingement crystallisation pattern, sparry limestone; B - highly elongated crystals, sparry limestone; $\mathbf{C}$ - lamina composed of microcrystalline calcite with admixtures of detrital non-carbonate components (e.g., quartz); D - ferruginous muddy limestone composed of crystalline clasts of Jurassic crinoidal limestone cemented with iron compounds

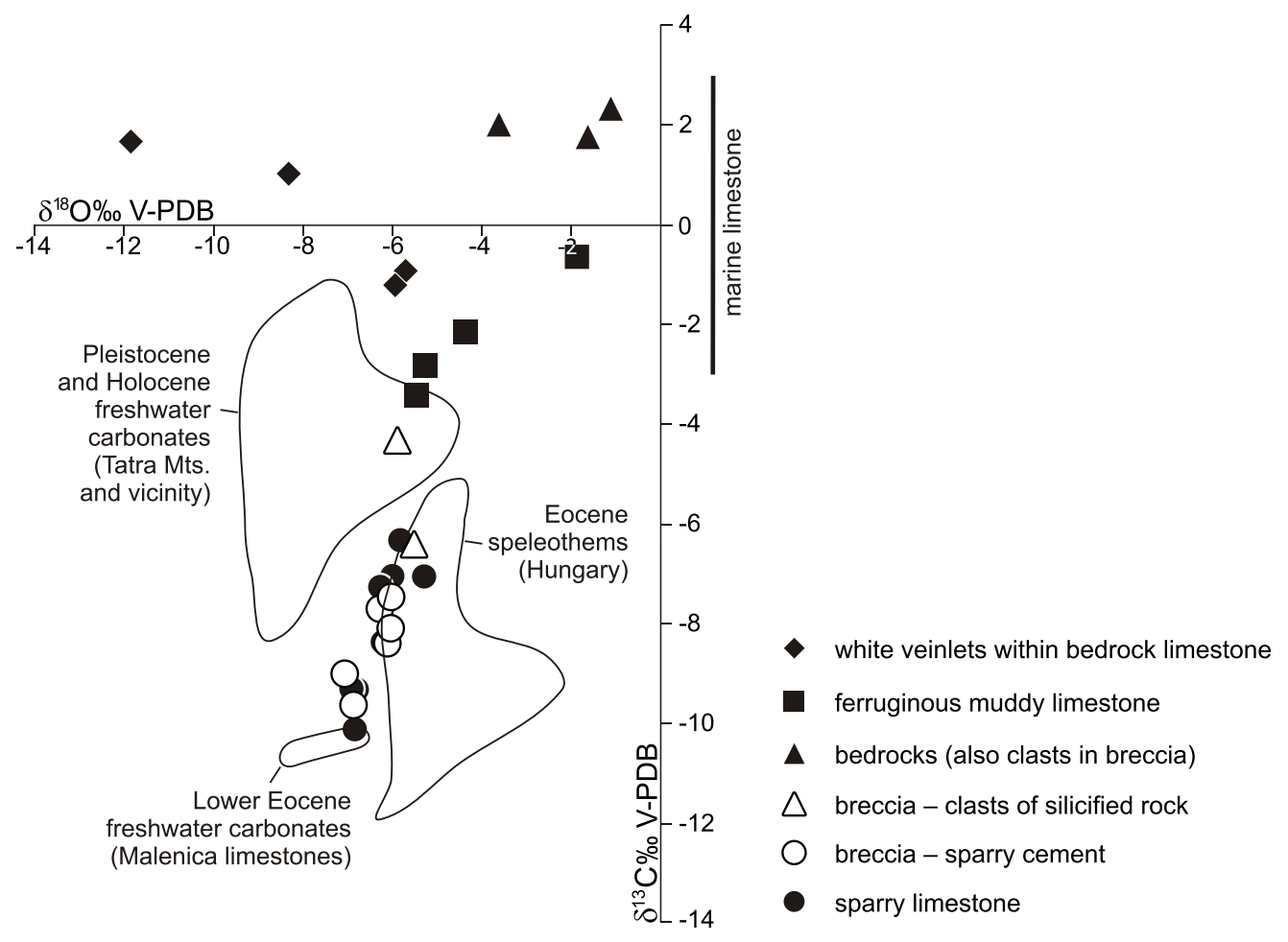

Fig. 5. Isotopic composition of the deposits studied

Data on isotopic composition of Holocene and Pleistocene freshwater carbonate after Gradziński et al. (2001, 2009, 2013), Hungarian Eocene speleothems after Gy ri et al. (2014), Malenica limestone after Repčok and Salaj (1998), range of $\delta^{13} \mathrm{C}$ of marine limestones after Fairchild and Baker (2012) 
T a ble 2 ternary speleothems has been abandoned or de-

Stable isotopic composition of the deposits studied

\begin{tabular}{|c|c|c|c|}
\hline $\begin{array}{l}\text { Sample } \\
\text { number }\end{array}$ & {$\left[\% \delta^{13} \mathrm{C}-\mathrm{PDB}\right]$} & {$\left[\%{ }^{18} \mathrm{O}\right.$} & Lithotype \\
\hline BK 1e & -4.31 & -5.89 & breccia - clast of silicified spiculite \\
\hline BK 1a & -6.39 & -5.52 & breccia - clast of silicified spiculite \\
\hline BK 13b & 1.04 & -8.32 & white veinlet within Jurassic limestone \\
\hline $\mathrm{BK} 6 \mathrm{c}$ & 1.68 & -11.85 & white veinlet within Jurassic limestone \\
\hline BK 17b & -0.90 & -5.71 & white veinlet within Jurassic limestone \\
\hline BK 17c & -1.19 & -5.94 & white veinlet within Jurassic limestone \\
\hline BK 6d & -2.15 & -4.38 & ferruginous muddy limestone \\
\hline $\mathrm{BK} 7 \mathrm{~b}$ & -0.64 & -1.87 & ferruginous muddy limestone \\
\hline BK 1k & -3.40 & -5.47 & ferruginous muddy limestone \\
\hline BK $12 \mathrm{~g}$ & -2.81 & -5.28 & ferruginous muddy limestone \\
\hline BK 7a & 2.34 & -1.12 & breccia - clast of basement limestone \\
\hline $\mathrm{BK} 17 \mathrm{a}$ & 2.03 & -3.62 & breccia - clast of basement limestone \\
\hline BK 13a & 1.78 & -1.63 & breccia - clast of basement limestone \\
\hline BK 12d & -7.04 & -6.00 & sparry limestone \\
\hline $\mathrm{BK} 6 \mathrm{~b}$ & -9.31 & -6.80 & sparry limestone \\
\hline BK $12 f$ & -7.05 & -5.29 & sparry limestone \\
\hline $\mathrm{BK} 12 \mathrm{c}$ & -6.31 & -5.83 & sparry limestone \\
\hline BK 6a & -9.29 & -6.92 & sparry limestone \\
\hline BK 12a & -7.25 & -6.28 & sparry limestone \\
\hline Sz 1a & -10.1 & -6.85 & sparry limestone \\
\hline Sz 1b & -8.35 & -6.22 & sparry limestone \\
\hline BK 1h & -7.69 & -6.28 & breccia - sparry cement \\
\hline BK 1d & -8.38 & -6.11 & breccia - sparry cement \\
\hline BK 1i & -9.62 & -6.88 & breccia - sparry cement \\
\hline BK 1b & -8.99 & -7.07 & breccia - sparry cement \\
\hline BK $1 f$ & -7.45 & -6.03 & breccia - sparry cement \\
\hline BK $1 \mathrm{~g}$ & -8.08 & -6.05 & breccia - sparry cement \\
\hline
\end{tabular}

\section{Results of U-series dating}

\begin{tabular}{|l|c|c|c|c|c|}
\hline Sample & Lab. No. & $\begin{array}{c}\text { U cont. } \\
\text { [ppm] }\end{array}$ & ${ }^{234} \mathrm{U} /{ }^{238} \mathrm{U}$ & ${ }^{230} \mathrm{Th} /{ }^{234} \mathrm{U}$ & ${ }^{230} \mathrm{Th} /{ }^{232} \mathrm{Th}$ \\
\hline BK 12 & 58 & $0.0869 \pm 0.003$ & $1.099 \pm 0.006$ & $1.22 \pm 0.01$ & $47.5 \pm 0.4$ \\
\hline
\end{tabular}

breccia also represents karst deposits. It originated within caves, which is shown by the presence of clasts of exclusively local rocks and, above all, by cementation of these clasts by spelean calcite. The ferruginous muddy limestone is a deposit composed of extraclasts derived from local rocks mixed with a residual matrix. The predominance of crinoidal limestone fragments most probably resulted from specific granular disintegration of this rock.

The stable isotopic composition of the sparry calcite - that is flowstones and the cement of the breccia - can shed some light on the conditions of its growth. It is commonly accepted that the $\delta^{18} \mathrm{O}$ of calcite reflects the temperature of crystallisation ( $\mathrm{O}^{\prime} \mathrm{Neil}$ et al., 1969; see also Hoefs, 1997 and literature quoted therein). However, this parameter also depends strongly on the isotopic composition of the parental water and on possible kinetic effects. Thus, it is impossible to estimate the temperature of crystallisation without additional data, or without making some extra assumptions. As a result of this, calculation of temperatures in high-resolution climate reconstructions based on Qua-
Table 3

mands additional data (see Fairchild and Baker, 2012). However, such estimations have been commonly made in a study of other freshwater carbonates, namely palaeosols (e.g., Dworkin et al., 2005 and references therein), and also palaeokarst deposits (e.g., Elliassen and Talbot, 2005). The Hays and Grossmann's (1991) equation is routinely used. It is formulated as follows:

$\mathrm{T}=13.3 \pm 32.6\left[-0.231-0.0631\left(\delta^{18} \mathrm{O}_{\mathrm{mcl}}+\right.\right.$ $\left.\left.\delta^{18} \mathrm{O}_{\text {sw. }}\right)\right]^{1 / 2}$, where mcl. and sw. denotes meteoric calcites and seawater respectively.

Applying this above equation, using the values of $\delta^{18} \mathrm{O}$ of the carbonates studied and assuming $\delta^{18} \mathrm{O}_{\text {sw. }}=0 \%$ a temperature range between 23 and $28^{\circ} \mathrm{C}$ was obtained, with a mean value of $26^{\circ} \mathrm{C}$. Clearly, these results must be treated with great caution.

The values of $\delta^{13} \mathrm{C}$ show that sparry limestone was fed with water charged with soil-derived $\mathrm{CO}_{2}$ (Fairchild and Baker, 2012). The values of carbonates studied are lower than analogue values of Holocene and Pleistocene freshwater carbonates (mainly speleothems) from the Tatra Mts. and their vicinity (Fig. 5). This suggests a denser vegetation cover during the crystallisation of the deposits studied than during the Pleistocene and Holocene in the Tatra Mts. The relatively negative values of $\delta^{13} \mathrm{C}$, ranging between -9.62 and $-6.31 \%$, imply a dominance of C3 pathway plants (see Dreybrodt, 1980; Baker et al., 1997). The ferruginous muddy limestone yields $\delta^{13} \mathrm{C}$ values higher than the flowstone and breccia cement but lower than the Jurassic host limestone. This results from a mixture of limestone extraclasts, which are isotopically heavier, and isotopically light cements (see Woolhouse et al., 2009; Gradziński et al., 2014).

\section{AGE OF KARSTIFICATION}

Although the precise spatial relationship between the deposits studied and the host Jurassic carbonates is not known, the location of the former just below the red conglomerate is significant. This strongly suggests that the deposits in question represent infills of pre-Eocene karst caves.

The possibility of a younger age cannot be ruled out without discussion. The deposits in the Kościeliska Valley were found at ca. 55 and $70 \mathrm{~m}$ above the valley bottom (site A and B, respectively). Estimating a rate of valley incision, one can expect relatively young karst forms and their infills in such a setting, notably Middle Pleistocene or younger. However, the lithology of the deposits studied differs markedly from that of Quaternary cave deposits in the Tatra Mts. There is a lack of red cave deposits clastic deposits or red-stained speleothems in the Tatra Mts. (Głazek and Grodzicki, 1996). Neither are the known cave deposits of this area cemented with iron oxide. Quaternary clastic deposits contain, in the sand fraction, material derived from crystalline rocks of the Tatra Mts. core and tectonic outliers, notably quartz, feldspars and micas (Wójcik, 1966; Gradziński and Szulc, 2014). Such detrital components occur also in Pleistocene speleothems there (Dziadzio et al., 1993). These have not been found in the samples studied, except for quartz which is exceptionally rare. This suggests that the deposits studied origi- 
nated in different conditions than did the Quaternary cave deposits in the Tatra Mts. Conversely, the iron-rich material bears some affinities to red residual deposits which are common in pre-Eocene karst in the Central Carpathians (Činčura and Köhler, 1995 - "palaeoalpine" according to their terminology).

The pre-Eocene age of the karst is additionally supported by other evidence, that is: (i) loss of uranium from the sparry limestone, and (ii) the stable isotope composition of the deposits studied, although neither of these provides unquestionable proof. The loss of uranium means that the carbonate system was "open", which enabled the diffusion of uranium. Such factors as time and temperature stimulate greatly the diffusion of uranium (van Calsteren and Thomas, 2006). Both factors were at work in the case of the pre-Eocene deposits which experienced an overburden of a few kilometres of Eocene-Oligocene and ?Miocene strata, which probably coincided with an increased heat-flux (Środoń et al., 2006; Anczkiewicz et al., 2013).

The isotopic composition of the spelean calcites studied, that is the sparry limestone and the sparry cements of the breccia, displays considerable differences from those of Quaternary spelean calcites of the Tatra Mts., as discussed above. Concomitantly, they share some similarities with Eocene spelean calcites from Hungary (Gy ri et al., 2014). This suggests similar environmental conditions of their origin, namely climate and vegetation cover. What is more, the above-calculated temperature of crystallisation, which equals ca. $26^{\circ} \mathrm{C}$, is very similar to the temperature postulated for the Late Eocene in the Tatra Mts. on the basis of plant communities. Worobiec et al. (2015) estimated this temperature at over $20^{\circ} \mathrm{C}$. The above values are in line with the sea surface temperature exceeding $20^{\circ} \mathrm{C}$ calculated for Eocene nummulitic limestone of the Central Carpathians by Soták (2010) and temperatures of sedimentation of the Lower Eocene Malenica freshwater limestone (Strážovske Mts., Slovakia) postulated to fall within a range of 23-27 ${ }^{\circ} \mathrm{C}$ (Repčok and Salaj, 1998). The plant community described from the Tatra Eocene with representatives of Lauracae (e.g., Eotrigonobalanus urcinervis and Daphnogene sp.) as well as the palm Nypa burtini point to evergreen forests of a warm and humid (annual rainfall over $1.000 \mathrm{~mm}$ ) climate (Głazek and Zastawniak, 1999; Worobiec et al., 2015 and references therein; see also Zachos et al., 2001). Such a climate is especially favourable for karst processes and efficient dissolution of carbonate bedrock (Ford and Williams, 2007: p. 80-81). The above conditions are in line with the relatively light isotopic composition of carbon of the spelean calcites studied. The views expressed above collectively lead to the statement that the deposits discussed are the infills of pre-Eocene karst forms. Thus, they provide unequivocal proof that karst features sculpted the Tatra Mts. before the Eocene transgression.

The precise age of the deposits and karst forms they filled is hard to estimate. They are covered with red conglomerates. However, bearing in mind the uncertainties concerning the age of the red conglomerates, the karst can be dated back even to
mid-Cretaceous (Głazek, 2000). A Cretaceous age seems to be less probable because karstification could have started after the significant erosion of overridden nappes, hence considerably after thrusting of the nappes, which is dated to the mid-Cretaceous (e.g., Passendorfer, 1978; Plašienka, 2008; Lefeld, 2009). The more probable scenario is that karstification immediately preceded Eocene transgression. It may have been associated with creation of an extensive polje hypothesized by Głazek $(2000,2004)$ on the basis of the occurrence and thickness distribution of the red conglomerates. It is noteworthy that the deposits discussed were found within Jurassic rocks which bordered the polje. Employing the results of recent sedimentological and tectonic analysis (Jach et al., 2012; Dąbrowska and Jurewicz, 2013, respectively) it can be presumed that the polje in question was bound by an active fault and that tectonics affected its subsidence. Such a phenomenon relates also to many recently existing poljes (Gams, 2013). The subsidence continued during the Middle and Late Eocene, and resulted in deposition of the thick succession of detrital limestone (Jach et al., 2012). Nonetheless, some doubts as to the age of these karst forms and their infills still exist, especially taking into account the more complicated Cretaceous-Paleogene geological history of the Tatra Mts. postulated by Birkenmajer (1999).

\section{CONCLUSIONS}

1. The deposits studied - sparry limestone, ferruginous muddy limestone and breccia - are the infills of subterranean karst forms. Sparry limestone originated as flowstone growing on a cave wall.

2. The $\delta^{18} \mathrm{O}$ values of sparry limestone and sparry cement of the breccia suggests their crystallisation in temperatures over $20^{\circ} \mathrm{C}$. However, these results are based on several assumptions.

3. Karst forms were created by water charged with soil-derived $\mathrm{CO}_{2}$ connected with vegetation dominated probably by $\mathrm{C} 3$ pathway plants. This is inferred from relatively negative values of $\delta^{13} \mathrm{C}$ of the spelean carbonates.

4. The location of the deposits studied as well as their textures and stable isotope composition collectively prove that they were formed before the Eocene transgression. Thus, they demonstrate unequivocally that the Tatra Mts. were subjected to karstification at that time.

Acknowledgements. Authorities of the Tatra National Park are kindly acknowledged for providing permission for the field study. R. Gradziński helped in the field in the summer of 2014. $\mathrm{K}$. Gradzińska is thanked for her perseverance which enabled us to finish this paper. The paper has greatly benefited from the constructive comments of reviewers P. Bosák and J. Soták, as well as of the editors T. Peryt and J. Zalasiewicz.

\section{REFERENCES}

Alexandrowicz, S.W., Geroch, S., 1963. Association de petits Foraminifères dans l'eocène de la Tatra (in Polish with French summary). Rocznik Polskiego Towarzystwa Geologicznego, 33: 219-228.
Anczkiewicz, A.A., Środoń, J., Zattin, M., 2013. Thermal history of the Podhale Basin in the internal Western Carpathians from the perspective of apatite fission track analyses. Geologica Carpathica, 64: 141-151. 
Andrusov, D., 1965. Geológia Československých Karpát. Zvázok III (in Slovak). Vydavatel'stvo Slovenskej Akadémie Vied, Bratislava.

Aubrecht, R., 2015. Paleokarst, neptunian dykes, collapse breccias, mud mounds. In: Guidebook for the field trips accompanying 31st IAS Meeting of Sedimentology held in Kraków on 22nd-25th of June 2015. (ed. G. Haczewski): 159-193. Polish Geological Society, Kraków.

Bac-Moszaszwili, M., Burchart, J., Głazek, J., Iwanow, A., Jaroszewski, W., Kotański, Z., Lefeld, J., Mastella, L., Ozimkowski, W., Roniewicz, P., Skupiński, A., Westwalewicz-Mogilska, E., 1979. Geological map of the Polish Tatra Mountains 1:30 000. Wyd. Geol., Warszawa.

Baker, A., Ito, E., Smart, P.L., McEwan, R.F., 1997. Elevated and variable values of ${ }^{13} \mathrm{C}$ in speleothems in a British cave system. Chemical Geology, 136: 263-270.

Bartholdy, J., Bellas, S.M., Ćosović, V., Fuček, V.P., Keupp, H., 1999. Process controlling Eocene mid-latitude larger foraminifera accumulations: modeling of the stratigraphic architecture of a fore-arc basin (Podhale Basin, Poland). Geologica Carpathica, 50: 435-448.

Birkenmajer, K., 1999. Gosau-type conglomerate in the Rusinowa Poland Area, Polish Tatra Mts: its relation to Lower Subtatric Nappe. Bulletin of the Polish Academy of Sciences, Earth Sciences, 48: 117-133.

Bosák, P., Horáček, I., Panoš, V., 1989. Paleokarst of Czechoslovakia. In: Paleokarst: a Systematic and Regional Review (eds. P. Bosák, D.C. Ford, J. Głazek and I. Horáček): 77-105. Elsevier, Amsterdam.

Č́čel, B., 1958. Contribution to the mineralogy of bauxites from the surroundings of Mojtín (in Slovak with English summary) Geologické Práce, Zprávy, 14: 40-55.

Činčura, J., 1998a. Alte Paleokarstplateaus am Ostrand des Wiener Beckens (Kleine Karpaten, Slovakei). Zeitschrift für Geomorphologie, N.F., 42: 255-263.

Činčura, J., 1998b. Main features of the pre-Gosau paleokarst in the Brezovské Karpaty Mts. (Western Carpathians, Slovakia). Geologica Carpathica, 49: 297-300.

Činčura, J., Köhler, E., 1995. Palaeoalpine karstification - the longest paleokarst period in the Western Carpathians (Slovakia). Geologica Carpathica, 46: 343-347.

Dąbrowska, M., Jurewicz, E., 2013. Character and structural evolution of the Mała Łąka Fault in the Tatra Mts., Carpathians, Poland. Acta Geologica Polonica, 63: 137-151.

Dickson, J.A.D., 1993. Crystal growth diagrams as an aid to interpreting the fabrics of caclite aggregates. Journal of Sedimentary Petrology, 63: 1-17.

Dreybrodt, W., 1980. Deposition of calcite from thin films of calcareous solutions and the growth of speleothems. Chemical Geology, 29: 89-105.

Dworkin, S.I., Nordt, L., Atchley, S., 2005. Determining terrestrial paleotemperatures using the oxygen isotopic composition of pedogenic carbonate. Earth and Planetary Science Letters, 237: $56-68$

Dziadzio, P., Ró niak, R., Szulc, J., 1993. Origin of the Pleistocene calcite flowstone of two cave (Jakinia Psia and Jaskinia Naciekowa) in the West Tatra Mts. (in Polish with English summary). Przegląd Geologiczny, 41: 767-775.

Elliassen, A., Talbot, M.R., 2005. Solution-collapse breccias of the Minkinfjellet and Wordiekammen Formations, Central Spitsbergen, Svalbard: a large gypsum palaeokarst system. Sedimentology, 52: 775-794.

Fairchild, I.J., Baker, A., 2012. Speleothem Science. From Process to Past Environment. Wiley-Blackwell, Chichester.

Ford, D., Williams, P., 2007. Karst Hydrogeology and Geomorphology. Wiley, Chichester.

Frisia, S., 2015. Microstratigraphic logging of calcite fabrics in speleothems as tool for palaeoclimatic studies. International Journal of Speleology, 44: 1-16.

Frisia, S., Borsato, A., 2010. Karst. In: Carbonates in Continental Settings. Facies, Environments and Processes. Developments in Sedimentology, 61 (eds. A.M. Alonso-Zarza and L.H. Tanner): 269-318. Elsevier, Amsterdam.

Gams, I., 2013. Tectonic impact on poljes and minor basins (case study of Dinaric Karst). Acta Carsologica, 34: 25-41.

Given, R.K., Wilkinson, B.H., 1985. Kinetic control of morphology, composition and mineralogy of abiotic sedimentary carbonates. Journal of Sedimentary Petrology, 55: 109-119.

Głazek, J., 1989. Paleokarst of Poland. In: Paleokarst a Systematic and Regional Review (eds. P. Bosák, D.C. Ford, J. Głazek and I. Horáček): 77-105. Elsevier, Amsterdam.

Głazek, J., 2000. Kras przedeoceński w Tatrach (in Polish). In: Materiały 34. Sympozjum Speleologicznego, Kościelisko, 20-22.10.2000 (eds. J. Baryła, M. Gradziński and M. Szelerewicz): 23-25. Sekcja Speleoologiczna Polskiego Towarzystwa Przyrodników im. Kopernika, Kraków.

Głazek, J., 2004. Kras przedeoceński w Tatrach (in Polish). In: Geologia Tatr, Ponadregionalny kontekst sedymentologiczny, 21-24.06.2004 r. (eds. M. Kędzierski, S. Leszczyński and A. Uchman): 85. Polskie Towarzystwo Geologiczne, Kraków.

Głazek, J., Grodzicki, J., 1996. Karst and caves (in Polish with English summary). In: Przyroda Tatrzańskiego Parku Narodowego. (eds. Z. Glowaciński, K. Klimek, Z. Mirek and H. Piękoś-Mirkowa). Tatrzański Park Narodowy, Zakopane.

Głazek, J., Zastawniak, E., 1999. Terrestrial plant fossils in the transgressive Paleogene littoral/flysch sequence of the Tatra Mountains (Central Carpathians). Acta Palaeobotanica, Supplement, 2: 293-301.

Goddard, G.M., Trask, P.D., DeFord, R.K., Rove, O.N., Singewald, J.T. Jr., Overbeck, R.M., 1970. Rock-color chart. Geological Society of America, Boulder.

González, L., Carpenter, S.J., Lohmann, K.C., 1992. Inorganic calcite morphology: roles of fluid chemistry and fluid flow. Journal of Sedimentary Petrology, 62: 382-399.

Grabowski, P., 1967. Geology of the Chocz scales of Upłaz, Kończysta and Brama Kantaka east of the Kościeliska Valley. Acta Geologica Polonica, 17: 671-696.

Gradziński, M., Szulc, J., 2014. Nacieki jaskiniowe (in Polish). In: Skały osadowe Tatr (eds. R. Jach, T. Rychliński and A Uchman): 243-250. Wydawnictwa Tatrzańskiego Parku Narodowego, Zakopane.

Gradziński, M., Rospondek, M., Szulc, J., 1997. Paleoenvironmental controls and microfacies variability of the flowstone cover from Zvoniv Cave in the Slovakian Karst. Slovak Geological Magazine, 3: 299-313.

Gradziński, M., Jach, R., Stworzewicz, E., 2001. Cementation of Holocene slope breccias in the Długa Valley (the Western Tatra Mts.). Annales Societatis Geologorum Poloniae, 71: 105-113.

Gradziński, M., Jach, R., Riding, R., Uchman, A., 2006. Słodkowodne stromatolity i onkoidy w zlepieńcach eoceńskich Doliny Suchej Wody w Tatrach (in Polish). In: II Polska Konferencja Sedymentologiczna, Materiały konferencyjne (eds. A. Wysocka and M. Jasionowski): 123. Instytut Geologii Podstawowej UW, Warszawa.

Gradziński, M., Hercman, H., Kicińska, D., Barczyk, G., Bella, P. Holúbek, P., 2009. Karst in the Tatra Mountains - developments of knowledge in the last thirty years (in Polish with English summary). Przegląd Geologiczny, 57: 674-684.

Gradziński, M., Jach, R., Górnikiewicz, E., 2013. Needle-fibre calcite and nanofibres as components of Holocene fissure-filling carbonates in southern Poland. Annales Societatis Geologorum Poloniae, 83: 229-242.

Gradziński, M., Hercman, H., Staniszewski, K., 2014. Middle Pleistocene carbonate-cemented colluvium in southern Poland: Its depositional processes, diagenesis and regional palaeoenvironmental significance. Sedimentary Geology, 306: 24-35.

Gross, P., Köhler, E., Samuel, O., Snopková, P., Bystrická, H., 1993. Subtatric group (Intracarpathian Paleogene) (in Slovak English summary). In: Geology of Southern and Eastern Orava (eds. P. Gross, E. Köhler, J. Mello, J. Haško, R. Halouzka and A. Nagy): 68-116. Geologický Ústav D. Štúra, Bratislava.

Gy ri, O., Orbán, R., Mindszenty, A., Fodor, L., Poros, Zs., Er ss, A., Benkó, Zs., Molnár, F., 2014. Red calcite: an indica- 
tor of paleo-karst systems associated with bauxite unconformities. Geofluids, 14: 459-480.

Hays, P.D., Grossmann, E.L., 1991. Oxygen isotopes in meteoric calcite as indicators of continental paleoclimate. Geology, 19: 441-444.

Hoefs, J., 1997. Stable Isotope Geochemistry. Springer, Berlin.

Ivanovich, M., Harmon, R.S., 1992. Uranium Series Disequilibrium. Applications to Environmental Problems. Clarendon, Oxford.

Jach, R., Machaniec, E., 2014. Skały eocenu (in Polish). In: Skały osadowe Tatr (eds. R. Jach, T. Rychliński and A. Uchman): 232-244. Wydawnictwa Tatrzańskiego Parku Narodowego, Zakopane.

Jach, R., Machaniec, E., Uchman, A., 2012. The trace fossil Nummipera eocenica from the Tatra Mountains, Poland: morphology and palaeoenvironmental implications. Lethaia, 45 342-355.

Kotański, Z., 1965. La structure géologique de la chaîne Subtatrique entre la Vallée de Mała Łakka et la Vallee Kościeliska dans les Tatras Occidentales (in Polish with French summary). Acta Geologica Polonica, 15: 258-330.

Kulka, A., 1985. Arni sedimentological model in the Tatra Eocene. Kwartalnik Geologiczny, 29 (1): 31-64.

Kuźniar, Cz., 1913. Skały osadowe tatrzańskie. Studium petrograficzne (in Polish). Rozprawy Wydziału Matematyczno-Przyrodniczego Akademii Umiejętności. Serya III, 13A: 131-176.

Lefeld, J., 2009. Alpine orogenic phases in the Tatra Mts (in Polish with English summary). Przegląd Geologiczny, 57: 669-673.

Lefeld, J., Gaździcki, A., Iwanow, A., Krajewski, K., Wójcik, K., 1985. Jurassic and Cretaceous litostratigraphic units in the Tatra Mts. Studia Geologica Polonica, 84: 7-93.

Machaniec, E., Jach, R., Gradziński, M., 2011. Morphotype variation of orthophragminids as a paleoecological indicator: a case study of Late Bartonian limestone, Pod Capkami Quarry, Tatra Mts, Poland. Annales Societatis Geologorum Poloniae, 81: 199-205.

Novotný, L., Tulis, J., 2002. Skalné Okno - Pre-Paleogenous karst in the Slovenský Raj (in Slovak with English summary). In: Výskum, využívanie a ochrana jaskýň (ed. P. Bella): 75-79. Správa slovenských jaskýň, Liptovský Mikuláa.

Olszewska, B.W., Wieczorek, J., 1998. The Paleogene of the Podhale Basin (Polish Inner Carpathians) - micropaleontological perspective. Przeglad Geologiczny, 46: 721-728.

O'Neil, J.R., Clayton, R.N., Mayeda, T.K., 1969. Oxygen isotope fractionation in divalent metal carbonates. Journal of Chemical Physics, 51: 5547-5558.

Osborne, R.A.L., 2007. Intensively lithified paleokarst deposits in Okno Cave, Demänovská Valley (Slovakia). Geologica Carpathica, 58: 565-578.

Passendorfer, E., 1978. Jak powstały Tatry (in Polish). Wyd. Geol., Warszawa.

Plašienka, D., 2008. The Western Carpathians. In: The Geology of Central Europe, 2: Mesozoic and Cenozoic (ed. T. McCann): 1181-1217. The Geological Society, London.

Radomski, A., 1958. The sedimentological character of the Podhale flysch (in Polish with English summary). Acta Geologica Polonica, 8: 335-409.

Repčok, I., Salaj, J., 1998. Distribution of $O$ and $C$ isotopes in freshwater Malenica carbonates (in Slovak with English summary). Zemný Plyn a Nafta, 43: 261-263.

Roniewicz, P., 1969. Sedimentation of the Nummulite Eocene in the Tatra (in Polish with English summary). Acta Geologica Polonica, 19: 503--608.

Salaj, J., 1991. Lacustrine limestone in Súl'ov conglomerates of the Pružina area and their significance for paleogeographical- -tectonical evolution of the area (in Slovak with English summary). Mineralia Slovaca, 23: 215-222.

Salaj, J., 1993. The Súl'ov Paleogene of the Domaniža Basin in the light of new findings. Geologica Carpathica, 44: 95-107.

Salaj, J., 2001. New knowledge of stratigraphy and paleogeographic-tectonic development of the Súlov type Paleogene (in Slovak with English summary). Mineralia Slovaca, 33: 81-90.

Salaj, J., 2002. Reflection of paleoclimate in Paleogene sediments of Súlov, Biele Karpaty and Javorínky areas (Slovakia). Mineralia Slovaca, 34: 147-158.

Schwarcz, H.P., Latham, A.G., 1989. Dirty calcites I: Uranium series dating of contaminated calcite using leachates alone. Isotope Geoscience, 80: 35-43.

Sokołowski, S., 1959. Geological map of the Nummulitic Eocene region - northern margin of the Polish Tatra (in Polish with English summary). Biuletyn Instytutu Geologicznego, 149: 197-213.

Soták, J., 2010. Paleoenvironmental changes across the Eocene-Oligocene boundary: insights from the Central Carpathian Paleogene Basin. Geologica Carpathica, 61: 393-418.

Sotak, J., Pereszlenyi, M., Marschalko, R., Milicka, J., Starek, D., 2001. Sedimentology and hydrocarbon habitat of the submarine-fan deposits of the central Carpathian Paleogene Basin (NE Slovakia). Marine and Petroleum Geology, 18: 87-114.

Starek, D., Sliva, L., Vojtko, R., 2012. Eustatic and tectonic control on late Eocene fan delta development (Orava Basin, Central Western Carpathians). Geological Quarterly, 56 (1): 67-84.

Środoń, J., Kotarba, M., Biroň, A., Such, P., Clauer, N., Wójtowicz, A., 2006. Diagenetic history of the Podhale-Orava Basin and the underlying Tatra sedimentary structural units (Western Carpathians): evidence from XRD and K-Ar of illite-smectite. Clay Minerals, 41: 751-774.

Uchman, A., 1994. Lower Jurassic carbonate sedimentation controlled by tilted blocks in the Choč Unit in the Tatra Mts., Poland. Zentralblatt für Geologie und Paläontologie, Teil I, 7/8 (for 1993): 875-883.

Uchman, A., 1997. Jednostka choczańska (in Polish). In: Przewodnik LXVIII Zjazdu Polskiego Towarzystwa Geologicznego, Zakopane 2-4 października 1997 (eds. J. Lefeld and A. Gaździcki): 94-98. Polskie Towarzystwo Geologiczne, Warszawa.

Uchman, A., 2014. Jura płaszczowiny choczańskiej (hronicum) (in Polish). In: Skały osadowe Tatr (eds. R. Jach, T. Rychliński and A. Uchman): 232-244. Wydawnictwa Tatrzańskiego Parku Narodowego, Zakopane.

van Calsteren, P., Thomas, L., 2006. Uranium-series dating applications in natural environmental science. Earth-Science Reviews, 75: 155-175.

Woolhouse, G., Andrews, J.E., Marca-Bell, A., Dennis, P.E., 2009 Geochemical constraints on the origin of enigmatic cemented chalks, Norfolk, UK. Geological Magazine, 146: 291-299.

Worobiec, G., Jach, R., Machaniec, E., Uchman, A., Worobiec, E., 2015. Eocene flora and trace fossils from the Hruby Regiel section in the Tatra Mountains (Poland): taxonomic revision of the Wiktor Kuźniar fossil plant collection. Acta Geologica Polonica, 65: 203-225.

Wójcik, Z., 1966. On the origin and age of clastic deposits in the Tatra caves (in Polish with English summary). Prace Muzeum Ziemi, 9: 3-130.

Wyczółkowski, J., 1956. On some lithological investigations on the Eocene deposits of the Kościeliska Valley in the Tatra Mts. (in Polish with English summary). Biuletyn Instytutu Geologicznego, 109: 45-57.

Zachos, J., Pagani, M., Sloan, L., Thomas, E., Billups, K., 2001. Trends, rhythms, and aberrations in global climate $65 \mathrm{Ma}$ to present. Science, 292: 686-693. 